structure of the house itself. In 168 houses, or $1 \cdot 2$ per cent, a serious degree of infestation was found, living bugs or eggs being present not only in the beds or on furniture but also in the structure of the rooms such as picture rail, skirting and door facings. In the great majority of houses infestation was detected at a fairly early stage by the nurse inspectors. The progress made in the prevention of any infestation during the last six years is shown by a fall from $10 \cdot 7$ per cent in 1934 to $2 \cdot 1$ per cent in 1939 and by a fall of serious infestation from $7 \cdot 1$ to $1 \cdot 2$ per cent during the same period.

\section{Public Health in Mexico}

According to the British Medical Journal of August 9, the National University of Mexico, four years ago, founded its social service system under which every medical graduate is required to practise for five months as a health officer in some part of the country where there is no such representative. $\mathrm{He}$ sends in a weekly report of contagious diseases cases seen, and a monthly report which includes information on sanitary questions such as water supply and drainage. Since 1935 more than a hundred graduates have taken part in this social service programme.

\section{Recent Earthquakes}

THE provisional epicentres of two earthquakes have recently been found by the United States Coast and Geodetic Survey in co-operation with Science Service and the Jesuit Seismological Association. The first, on June 18, 1941, had its epicentre near lat. $51 \cdot 5^{\circ} \mathrm{N}$., long. $32^{\circ} \mathrm{W}$., which is in the North Atlantic Ocean on the ridge which stretches from Greenland to the Azores. Occasional earthquakes are known to occur from time to time on this ridge, showing that it is still one of the unstable regions of the earth. The second shock, on June 26, had its epicentre near lat. $13^{\circ} \mathrm{N}$., long. $93^{\circ} \mathrm{E}$., which is near the Andaman Islands in the Bay of Bengal.

Sixteen large distant earthquakes were registered on the seismograms at Kew Observatory during August 1941. The greatest was on August 2, when a ground amplitude of $91 \mu$ was attained at Kew, and a full suite of pulses was obtained on August 4, 6, 9, 15 (see Nature, Sept. 13), 19, and 30. The shock on August 6 at an estimated epicentral distance of $8,800 \mathrm{~km}$. had a probable depth of focus of 200 $\mathrm{km}$. On August 9 there were six shocks, five being from an estimated epicentral distance of $2,030 \mathrm{~km}$.

\section{The Night Sky in October}

THE moon is full on Oct. $5 \mathrm{~d} .8 \mathrm{~h} .32 \mathrm{~m}$. and new on Oct. $27 \mathrm{~d}$. $20 \mathrm{~h} .9 \mathrm{~m}$. There will be an occultation of the first magnitude star $\alpha$ Tauri on October 10, the disappeàrance as seen from Greenwich taking place at $3 \mathrm{~h} .16 \cdot \mathrm{Im}$. and the reappearance at $4 \mathrm{~h} .30 \cdot \mathrm{lm}$., the position angles being $290^{\circ}$ and $252^{\circ}$ respectively. Lunar conjunctions with the planets will be as follows: Mars on Oct. 5d. 23h., Mars $1^{\circ} \mathrm{S}$.; Saturn on Oct. 9d. 4h., Saturn $2^{\circ}$ N. ; Jupiter on Oct. 11d. 4 h., Jupiter $5^{\circ}$ N.; Venus on Oct. 23d. 17h., Venus $8^{\circ} \mathrm{S}$.
Mercury is an evening star until Oct. 26 and then becomes a morning star. Venus is an evening star and sets at $18 \mathrm{~h} .38 \mathrm{~m}$. at the beginning and at $18 \mathrm{~h} .19 \mathrm{~m}$. at the end of the month. Mars is a morning star until Oct. 10 when it is in opposition to the sun, and then it is an evening star. At the beginning and end of the month the planet souths at $0 \mathrm{~h} .41 \mathrm{~m}$. and $22 \mathrm{~h} .6 \mathrm{~m}$. respectively. Jupiter is a morning star and crosses the meridian at $4 \mathrm{~h} .44 \mathrm{~m}$. on Oct. 1 and at $2 \mathrm{~h} .44 \mathrm{~m}$. on Oct. 31. Saturn is a morning star, the meridian passages being at $3 \mathrm{~h} .8 \mathrm{~m}$. and $1 \mathrm{~h}$. $7 . \mathrm{m}$ at the beginning and end of the month respectively. The Orionid meteor shower will commence about Oct. 18 and will continue for a few nights ; the radiant point is close to $\nu$ Orionis. Comet van Gent (1941d) will be visible with the aid of a small telescope during the month. It will be easily identified, a 3 -inch refractor showing it quite distinctly, as its magnitude is about $8 \cdot 5$. The comet is moving northward in declination in the constellation Ursa Major, and on Oct. 19 will be close to $\psi$ Ursæ Majoris. Its distances from the earth and sun in the middle of the month will be nearly the same-about 108 million miles. Although it is receding from the Sun it is still approaching the Earth, for which reason its magnitude will not vary very much during the month, that due to the increase in distance from the Sun being nearly balanced by the change due to the decrease in distance from the Earth. An ephemeris for every four nights is given for the comet. A short ephemeris was given in NATURE of Aug. 2, p. 139.

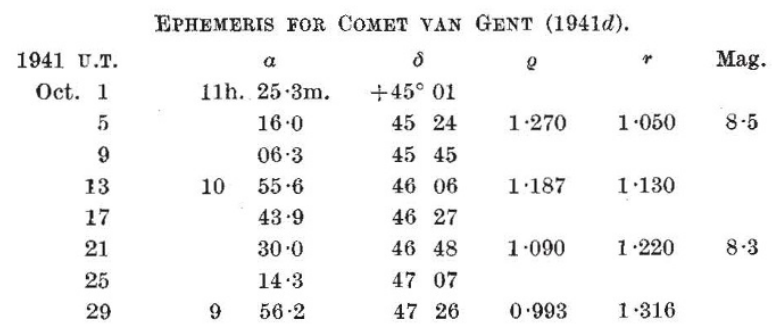

\section{Announcements}

Dr. W. H. Mills, F.R.S., emeritus reader in stereochemistry in the University of Cambridge, has been elected president of the Chemical Society until the next annual general meeting.

A meeting to celebrate the tercentenary of the arrival of Comenius in London will be held at the Caxton Hall, London, on September 29. The Archbishop of York will preside, and the principal speakers will be the Prime Minister of the Netherlands and the Foreign Minister of Czechoslovakia. A further meeting will be held at Cambridge on October 24 (see Nature, Aug. 23, p. 222).

Erratum. In the letter entitled "Specific Heat of Supra-Conductive Tantalum" by Dr. K. Mendelssohn in NATURE of September 13, p. 316, the graph as printed is inverted. It should be read as if turned through $180^{\circ}$, without shifting the numerals of the ordinates. 